\title{
Ten Things Faculty Should Know Before Stepping Into Administration
}

\author{
Randy Settoon, Southeastern Louisiana University, USA \\ Rusty Juban, Southeastern Louisiana University, USA \\ Michael C. Budden, Southeastern Louisiana University, USA
}

\begin{abstract}
Every year professors leave the ranks of the faculty and become members of the administration. Yes, even jaded faculty sometimes become members of the administration and have to pursue charges and challenges previously unrecognized or unfathomed. It is to these individuals the authors have prepared a list of ten items they feel all potential college and university administrators should be aware of before making the commitment. These items should not be construed to be a roadblock, but rather advance notice that the life of an administrator is very different from that of faculty member.
\end{abstract}

Keywords: Administration, faculty development

\section{INTRODUCTION}

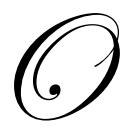

ne of the authors of this paper had promised himself early on they would never become a member of the "administration." After all, teaching and researching was what the author enjoyed and were the primary incentives behind the pursuit of the doctorate which would allow a life-long pursuit of personal interests as a faculty member. Then it happened. His current dean and former department head approached the author and asked him to apply to be department head. The request, the first of several was politely refused.

After several requests were refused, the dean came to the author and related that if he was unwilling to serve as department head, there was another faculty member who was more than willing to serve - in fact, that individual wanted the position and had approached many to garner support for his candidacy. Given this prospect the faculty member who never wanted to be anything other than a faculty member had accepted the position and moved into the big office. Little did he know the decision to become department head would change everything. The following is a list of ten things it would have been helpful to know.

\section{TEN THINGS FACULTY SHOULD KNOW}

1. Administrators are pulled between two worlds - the world of administration and the world of faculty. In most colleges, administrators carry faculty rank and have faculty responsibilities - albeit to a lesser extent than full time faculty. Academic administrators, i.e. department heads and chairs often work on two planes of existence. The expectation is there from peers and administrator's to publish and produce grants and funding. But department heads are burdened with administrative duties such as managing office staff, complying with requests from other administrators for student/faculty information, overseeing equipment audits, and handling all sorts of complaints - i.e. the restroom is flooding, the copy machine is out of order, printers need cartridges and requests for leave, to name a few items. In a typical administrator's day there is little time to address academic tasks and responsibilities. Gone are the days when papers could be hammered out on a Friday afternoon when there are no courses to teach. Academic pursuits are now moved to Saturdays and Sundays taking time away from family and other responsibilities. In a similar vein, being an administrator is like straddling a fence with the desire to be either on the side of the "academics" or the "administration." In the classroom an administrator often may wish that administration 
would provide more funds toward certain programs, or eliminate pesky policies, only to catch themselves by realizing "they are the administration."

2. Herding cats is hard work and has commonalities with academic administration. Managing faculty can be difficult when concepts like "academic freedom" are misinterpreted and these misinterpretations are ingrained into the academic mindset. As a whole, faculty understand that rules and policies must be followed with regard to holding class, filing out paperwork on students, purchasing items, and seeking reimbursement for expenditures. However, some faculty may feel that these rules do not apply because they are a champion in an idealistic battle between faculty educators and the "establishment." Sometimes, such faculty tout their rebellion against administration, seeing attempts by the administration to discipline inappropriate behavior as a badge of honor. Reacting too strongly to these issues or taking them personally can also create problems. When an administrator steps down and integrates back into faculty, harsh actions and words can come back to haunt them.

3. Taking on tenure is never a pleasant task. Schools that offer tenure sometimes create problematic situations when it comes to evaluating and correcting faculty performance issues. Committees of peers often create the rules and ultimately have a say in the evaluation of tenure-track faculty. While these bodies are empowering to faculty, they also take away from administrators some of the ability to make subjective decisions on faculty employment. While it is common knowledge that it is difficult to terminate a faculty member once they have tenure, it is a misconception that tenure provides ultimate protection from a disgruntled and low performing professor. The battle cry, "But I have tenure!" may rally the old guard into a defensive position around a troubled colleague, but as an administrator it is unacceptable to have faculty who stop contributing after earning tenure. Still, to enforce policy, all must be held accountable for their actions. Tenure should not be an issue in a discussion of low productivity, but too often it becomes one.

4. Seeing how sausage is made can jade even the staunchest of hearts. As a child one of the authors was horrified when on a tour of a local meat processing plant he was able to observe the making of hotdogs. After that day, he never looked at a hot dog the same way. In the same way, faculty who have not previously served as administrators know little about the business side of the enterprise. It is often true that former administrators make great faculty members. For often, they have seen and experienced first-hand the ins and outs of managing an academic unit with too few resources and too many charges. When it comes down to it, politics and not ideals, play an important role in how budgets are funded. Once the decision is made to become an administrator and you are privy to the budgeting process, it is hard to regain the "bliss of ignorance" that many non-administrators enjoy.

5. Be prepared to be seen in different light (or it's lonely at the top). Friends who were former colleagues will now view you in a different light. Indeed, administrators are expected to set goals and assess performance of faculty members. It is this new role where one is assessing former colleagues where much consternation can arise. A former dean once observed that no dean has friends. For a people-oriented person, becoming a dean presents challenges.

6. Be prepared to not know everything. As one administrator once said, he didn't know all of the questions, let alone all of the answers. As a new administrator, you should seek the advice and counsel of your supervisor. Also, your administrative assistant will hopefully know the ins and outs of the office well enough to lend insight that will prove of value to a new administrator. Finally, do seek the assistance and knowledge of your faculty. Faculty, especially senior faculty, will have much influence in the budget unit. Their advice (and support) may prove invaluable as you pursue your new tasks and challenges.

7. Be prepared to say no. Seldom, if ever, are resources limitless. There are limits on what an administrator can and should approve. With so many issues facing modern educational administrators, one must be willing to say no. All three of the authors have at times, wished they could have approved specific requests, but due to a variety of reasons, had to decline them. 
8. Be prepared to overrule faculty. A faculty member had a statement in their syllabus that "should a student miss three classes, the student would be dropped from the course." The university had a specific grade appeal process which allowed students to appeal grades, first to the faculty member, then to the department head, and finally to the dean. According to policy, the dean's decision was final. A student in the class with the above syllabus statement stopped going to class after the first day when the syllabus was distributed and discussed. The student decided they did not want to be in the class and just quit going. The student received an " $F$ " in the course upon the release of semester grades. The student followed the process - first going to the professor. The student explained that it was his understanding that the professor of the course (a senior professor with years of experience) would "drop" him from the course because of the statement in the syllabus and comments made the first day of the course emphasizing the policy. The professor's response to the appeal was a denial, based on their interpretation of the statement that a drop was possible but not required, hence the grade of "F" given to the student. The department head found with the faculty member understanding that the professor was adamant that the statement declaring a student would be dropped from the course was an example of the consequences, not the requisite outcome. As expected, the student appealed the "F" to the dean. The dean reviewed the student's statement, read the syllabus statement, and listened to the faculty member explain that they had a right to drop the student, but that the threat of dropping was just that, a threat, not a promise. The dean reviewed the findings of the department head. The faculty member argued that the grade of "F" was appropriate as the student had not returned after the first day of class and as a result, had not completed any work in the course. The dean quickly ruled for the student - irritating the senior faculty member. The statement was clearly written. The professor was wrong. The student should have been dropped, and retroactively was dropped from the course by the dean.

9. Be prepared to make decisions quickly. There are a few issues that require substantial time and effort. Budgeting, personnel assessment, recruiting, and some other issues can take considerable time and effort to do well. However, the majority of issues that a university administrator will face can be dealt with quickly. One must learn to recognize when a quick decision is best - as spending time and energy on issues of small importance - will only work to wear down the faculty member. Make the decision and move on. If it was not an optimal decision, then perhaps it can be addressed later. However, one will be amazed at how addressing issues quickly and decisively will ease other burdens.

10. Recognizing it's time to step back down. The old adage, "Be careful what you wish for," is appropriate in academic administration. Becoming an administrator means having a new career path with opportunities to rise to higher levels within the university. There are new challenges and opportunities to make a difference on a broad scale within the university. On the other hand, most academics begin their career because they love researching and teaching. They pursued their doctorate and attained tenure because they were good at their job. But as an administrator they may miss the student interaction in the classroom, the time spent researching and getting acceptance letters, and the camaraderie of their peers. In the summer when the days are long and the rest of the faculty are vacationing, when the paperwork for accreditation is backing up, and when a hundred other administrative details need attention, a little voice inside my head says "What was I thinking!"

\section{CONCLUSION}

The three authors have more than 30 years of administrative experience between them. Comments and concerns mentioned above should be considered before stepping into an administrative position. However, these comments should not be construed to be a condemnation of administrators, nor a recommendation that one not consider being an administrator. Indeed, all three authors believe administrative work to be rewarding and invigorating. Serving as an administrator allows one who cares to move the unit forward, support student and faculty growth, and provide personal opportunities that otherwise would be out of reach. Administrators have the power to help and serve others in ways that faculty members are unable to accomplish. It is for this reason that all three accepted the responsibility of an administrative appointment. 
As an aside, we would like to have included a more thorough list for those wishing to become an administrator. There were easily five more things that could be included, but we didn't have the time as two of the authors are still very busy being administrators.

\section{AUTHOR INFORMATION}

Dr. Randy Settoon is Dean of the College of Business and Professor of Management at Southeastern Louisiana University. His research interests include college development, leadership, organizational behavior and management.

Dr. Rusty Juban is Head of the Department of Management and associate professor of management at Southeastern Louisiana University. His research interests include faculty development, organizational development, and business education.

Dr. Michael C. Budden is the Mayfield Professor of Marketing at Southeastern Louisiana University. With 20 years of administrative experience, Budden's research interests include commercial law, international marketing and business education.

\section{NOTES}

